\title{
Representation of Conventional Gender Roles in Prasad
}

\author{
Asmita Bista \\ Lecturer \\ Department of English, Mahendra Multiple Campus, Tribhuvan University, Nepal \\ asmitabista15@gmail.com \\ DOI: https://doi.org/10.3126/dristikon.v11i1.39130
}

\begin{abstract}
The film Prasad reveals the prevailed gender practices in Nepali society that instigate to perform the stereotyped gender roles to the characters. So, the study aims to investigate how do characters construct the conventional gender identities. Likewise, this article intends to assess the reasons that force the characters to firmly stick to the prescribed gender roles. Similarly, to examine the consequences the characters go through while performing the traditional gender roles, is another objective of this article. To meet these objectives, Gender studies has been used as theoretical tools. Particularly, Judith Butler's, and R.W. Connell's idea of gender theory has been used. These theorists propose theory of gender as constructed phenomenon that is achieved through the constant performance. This article contributes to understanding the harmful consequences caused by conventional gender roles to the people. The study concludes that assigning the stereotyped gender roles to the characters, the film Prasad indorses the existing gender stereotype.

Keywords: gender roles, performativity, masculinity, femininity, patriarchy, social norms
\end{abstract}

\section{Introduction}

\section{Origin and Legacy of Nepali Film}

From Satya Harishchandra (1951), the first ever documented Nepali film, directed by D.B. Pariyar, to the film Aama 'Mother' (1964) it took the industry thirteen years to move a step further in producing the film that deals gender issue. The film Aama, directed by Hirasingh Khatri, was produced with the objective of spreading the feelings of nationality and patriotism among the Nepali people (Subedi, 2012, p.95). Nevertheless, depicting the changing paradigm of two generations of females' and males' roles in the familial and societal life, their status, and relationship between each other, this film appears as a pioneer in Nepali film industry. After the production of Aama, the films such as Maitighar that presents the courageous and successful journey of a widow, and Paraalako Aago, which are made on social themes, focuses on the subjects of female domination and domestic violence. 
Since the restoration of democracy in 1990 established people's right to freedom, speech, and broadcasting, film makers get a constructive environment for producing films. Consequently, enjoying the liberal environment of the nation, the Nepali film makers produce the films such Kanyaadan (1991), Deuki (1994). These films promote gender equality. Kanyaadan (1991) condemns the wrong social practices of child marriage and advocates for widow marriage. Likewise, the film Deuki (1994) criticizes an age-old tradition called deuki 'young girl offered to temple' (deuki cannot marry and end up being prostitute) that prevails in West Nepal. However, most of the films produced after 1990s cast the male character as a lead of the film. Adhikari (2018) has revealed that, "In the films those were produced after 19990s, the main plot is weaved to explore the conflict between good and evil. Obviously, good is represented by the hero and evil is represented by the villain" (p. 65); however, both are males. Adhikari has noticed that in the films such as Annyaaya (1990) directed by Tulsi Ghimire, Chot (1991) directed by Shyam Rai, Kanyaadaan (1991) directed by Prakas Thapa, Jhuma (1992) directed by Pradip Upadhyaya, Balidaan (1993) directed by Tulsi Ghimire, hero gets lead role and he is assigned to the role of a savior, whereas the heroine performs the role of weak, dependent being who need the help of a male to get rescued from the clutch of wicked and malicious male villain. In fact, in 90s majority of Nepali films reflect the social mechanism of Nepali society that provides major roles to the males, presenting them in conventional gender image, whereas the female characters are assigned to the roles of submissive, demure, and dependent person.

Similarly, since post-people's movement II converted the country into a republic state, Nepali film industry explores the issues of gender, ethnicity, and reformatory social practices. Chapagain (2015) has pointed out that Nepali films, produced in 2000s, reflect people's consciousness to their rights, equality, and freedom (p. 218). Similarly, in Tamang's (2002) observation, after 2000s, through the film such as Numafung women's issues come to the forefront of the patriarchal Nepali society (himalmag.com). In fact, after 2000s, more varied roles have been assigned to both the female and the male characters in Nepali films. However, variation does not eliminate typicality of roles. Most of the Nepali films continue to focus on males' point of view. Dixit (2019) has claimed that, Nepali filmmakers have not yet freed themselves from the conservative and narrow thought; therefore, they still present the female characters negatively. Citing the example of the film Machha Machha, Dixit has opined: "This film isn't just misogynist, it's also racist" (kathmandupost.com). Likewise, Newar (2003) has unraveled, Nepali films reinforce the imbalanced gender roles the male and female characters. In Newar's perception, presenting Nepal's favorite leading man in action; Nepali films reinforce the stereotyped gender roles, in which unbelievably strong hero defeats dozens of macho males, whereas feeble female character seems to be waiting for her prince charming to rescue her from the problematic situations (nepalitimes.com). Actually, though the films 
produced in the contemporary era raise gender issues, these films pertinently reflect the prevailed gender stereotypes of Nepali society that assigns stereotyped gender roles to the people. Allocating the conventional gender roles to the characters, Dinesh Raut's Prasad also becomes a part of this trend of film making.

Presenting the story of the struggle of a couple, who are from a nearby village of Baglung and are migrated to the capital city, Prasad provides a different taste to the Nepali film lovers. Through this couple, the film depicts the existing discriminatory caste system of Nepal. The main plot of the film revolves around the relationship of this couple that goes through highs and lows due to unfavorable situations, scarcity, shattered dreams, and misunderstandings. The film captures the struggles of outsiders in the capital city. The condition of the main characters Narayani and Baburam reproduces the problems of the common people of Nepali society. Likewise, Prasad makes its distinct place among the Nepali society by using the dialect of mid-western region in the dialogue of the main leads of the film.

Prasad is one of the least reviewed films of Nepali film industry. The review present by Pyakurel (2018) has provided some insights about the film. Pyakurel has underscored that Prasad succeeds to draw the audience to movie theaters because the story of this film is "unified into a single thread. It does not include any scene that is not connected to the overall plot and the intended message" (par. 3). Likewise, in Pyakurel's perception, the film does not bore the audience even for a single moment because "The writer has inserted meanings in very minor scenes, too. In general, no scene is wasted. Everything is neatly knitted together" (par. 7). Similarly, highlighting the literary elements in Prasad, Pyakurel has revealed that the movie is ironic in the use of visual and auditory symbols. The film symbolically represents the emotional bond that the couple shares in the strange land, through the shots in which the heroine recurrently visits to the hero at his workplace with a tiffin box. In the same manner, rain and storm symbolize the heroine's fear in the movie. In his review, Pyakurel mainly has illuminated the technical aspects of Prasad. Hence, he has left the scope for the researchers to analyze it from the perspective of gender theory.

\section{Materials and Methods}

To meet the objectives mentioned in the abstract, this article uses the qualitative research model. This film has been used as primary text because Prasad has enunciated the gender issues prevailed in contemporary hetero- normative society of Nepal. Similarly, to justify and validate the arguments of this research work, the ideas and arguments are taken from the social phenomena such as criticisms made on this film, experts' views. Apart from that, for the interpretation and analysis of this cinematic text, books on gender theory, and research documents published by various institutions have been used. These materials have been used as the secondary source, which have been collected through library sources, books, and websites. 
This research is based on the idea that gender is a socially constructed phenomenon that is instituted and controlled through social and cultural norms. So, this realm of knowledge has laid the foundation to form the arguments of this thesis. The arguments are: in the selected text, the gender roles and identities of every individual, the male, the female are constructed through social norms and values, which are imposed through socially produced script and social practices. Similarly, not only the female but the male also goes through anguishes and difficulties due to the gender biased social practices. These arguments have been validated through the theoretical concepts of gender theorists.

The academic study of gender and its development was activated by second wave feminism during the 1960s. Noticing the exclusion of the experiences, interests and identities of women in academic disciplines, second wave feminists design the course 'Women's Studies' with the purpose of eliminating women's domination, making women visible and criticizing male-centered ways of knowing and eradication of women's oppression. Kimmel and Aronson (2004) underscore that women's studies course is designed to make people "acknowledge about the hidden history of exemplary women" (p. xv). After the arrival of Women Studies in academia, men also started to make their presence through Men's Studies. As Capraro (2004) points out "In 1970s, men minutely observed the prospect of change for women in society and pursued its implications for men. Then, they started men's movement and started Men's Studies as its intellectual companion" (p. 534). Capraro underscores that men's movement starts with the purpose of making men self-reflective about the negative consequences of masculinity-for women and/or for men themselves, and to rethink of masculinity. Later, when both of these disciplines could not meet their objectives as they focused on the singular and rigid status of men and women, they get merged under 'gender studies' (Pilcher \& Whelehan, 2004, p. xii). Likewise, the concept of gender develops as a complex, multi-faceted, and multi-disciplinary area.

Gender theorists bring the idea that individual's gender is construction or representation that is achieved through discourse, performance and repetition rather than being real entities. Butler defines 'gender' as a human construct enacted by a vast repetition of social performance. Butler gives emphasis on the artificiality of gender and asserts that gender is constructed through the coherent enactment of prescribed acts. Butler (2007) suggests that the identity that an individual expresses is "fabrications manufactured and sustained through corporeal signs and other discursive means" (p.185). She argues that the gendered body has no ontological status apart from the various acts which constitute its reality. In fact, gender is an effect of performance and imitation over time as Butler (2007) asserts: "gender is an identity tenuously constituted in time, instituted in an exterior space through a stylized repetition of acts" (p. 191). Butler discloses that the cultural constructions constitute the idea of gender, but without the constant practice and imitation of them gender does not exists. 
Likewise, Connell (2000) underscores that "gender is defined collectively in culture and is sustained in institutions (Men and the Boys, p. 11). In Connell's (2009) perception, "man and woman is a becoming, a condition actively under construction" (p. 5). Connell unravels that gender is a process that is influenced by various factors socio-cultural taboo, customary socio-cultural practices and socio-cultural norms and rules. Similarly, Haraway (1991) argues that "Men and women are socially constituted and positioned in relations of hierarchy and antagonism" (p. 131). She views that personal and collective identity is precariously and constantly socially reconstituted (p. 148). These theorists argue that gender identity is a process that goes through social and cultural norms, rituals and practices; consequently, men and women get accustomed to recognize their respective places in social and familial hierarchy. Following the same line of argument, this article evaluates the characters' gender roles in Prasad.

\section{Results and Discussion}

\section{Portrayal of Stereotyped Gender Roles in Prasad}

Dinesh Raut's directed Prasad confirms the existing value system of Nepali society that confines people to the conventional gender roles. Presenting the conjugal life of the couples, the film reveals the pains of female characters caused by unequal power relations between husband and wife. The main plot Prasad revolves around newlywed couple Narayani Karki and Baburam Pariyar who have done inter-caste marriage. The film unravels the difficulties the couple goes through while settling down to the capital city Kathmandu. Equally, the film reveals the couple's struggle in maintaining the socially prescribed gender roles. In the beginning, both Narayani and Baburam seem enjoying equal position in the family hierarchy. Both of them boldly take decision against the discriminatory caste system and face the results as well. Likewise, after reaching Kathmandu, Baburam manages to get the shelter in his friend's house, whereas Narayani succeeds to gain a rented room by tricking the land-lady, when due to their belongingness to so-called low caste, they have been facing one after another rejection from the landlords/landlady.

When the story of the film moves forward, the characters seem to be restricted to the stereotyped gender roles due to which Narayani shrinks in the role of timid, duty-bound, submissive wife. On the contrary to her, Baburam appears in the roles of an assertive and authoritative husband. It happens after he sets up himself in the role of a sole bread-earner of the family. After earning money, he starts exercising his authority over his wife Narayani. He recurrently makes her realize that she is dependent on him. Likewise, Narayani, also gets convinced that she is reliant to Baburam. Consequently, constrained herself to the role of a devoted and dutiful wife, she cooks meal, does cleaning, dresses her husband and even polishes his shoes. 


\section{Figure 1.}

Narayani Devoting Herself in Baburam's Service

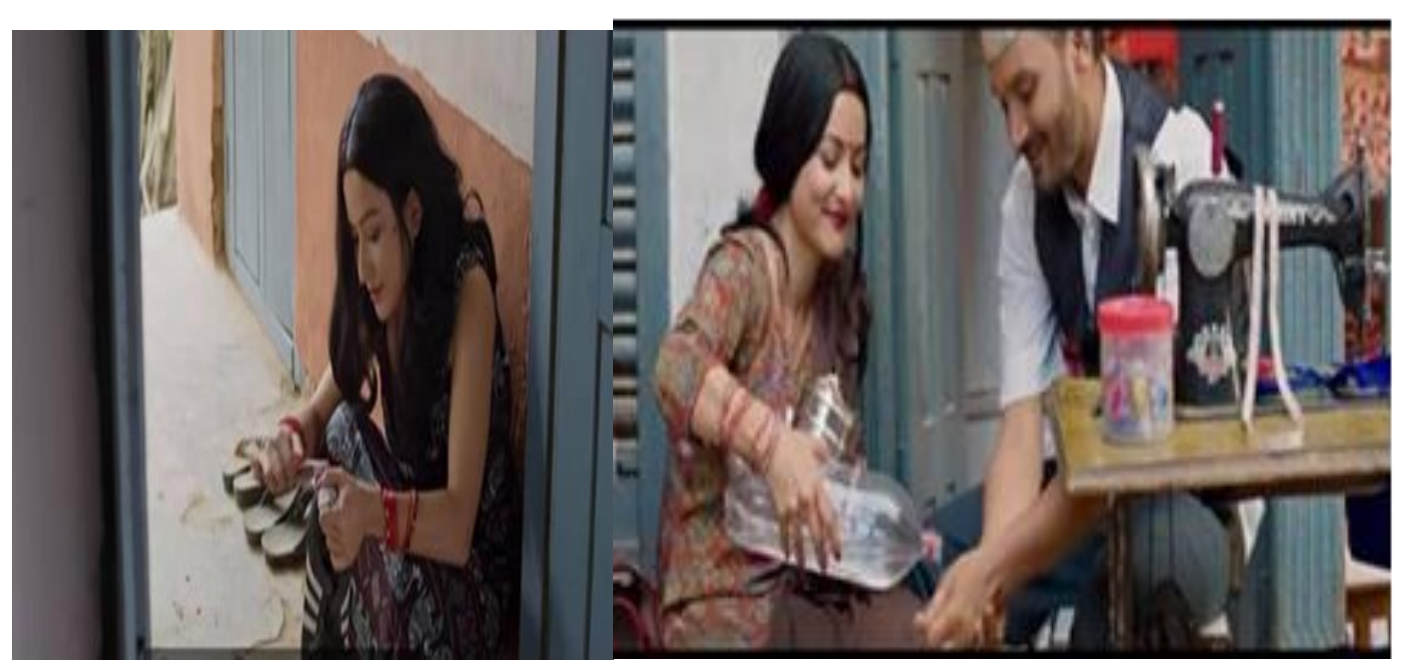

Source. Author's screenshot.

In these shots, paying her devotion to her husband, Narayani polishes Baburam's shoes at home and she pours water to wash Baburam's hand in his workplace. She makes meal, brings it to his work place to feeds him. Her situation confirms that "at the point of her marriage, a young woman often has no rights in her married home, only obligations" (McHugh, 2001, p. 89). In fact, after marriage, she gets more constrained into the traditional gender role. McHugh (2001) claims that "for the woman, marriage is a scenario of loss" (p. 89). After her dependency in Baburam, her freedom as well as self-esteem get repressed under Baburam's wishes and needs. So, when Baburam demands her to bring the meal to the work place, she responses that, "aba aaphno budo laai khaajaa lyyaunu ke thulo kuro bhayo ra? Din bhari ta ghar mai baschhu [it is not a big deal taking lunch for my husband. The whole day, I stay idly at home]" (Prasad). Actually, Narayani goes through a kind of suppressed mentality as she thinks guiltily that bearing her responsibility, Baburam needs to toil hard.

Depicting the daily activities of this couple, Prasad provides a porthole to the specificities of the patriarchy that controls life in one corner of the country. Most importantly, the fundamental extraordinariness of this film lies in its amazingly sensitive treatment of the 
woman by recurrently presenting her in the role of a frail woman. In one of the shots of the film, the camera frames the scene in a restaurant where a man stares Narayani while Baburam and Narayani are having some food. Then performing the role of a protector of his wife, Baburam changes the seat and creates a shield to her so that she gets hidden behind his body. As Derne (1994) reveals that "a male member considers, female is unsafe outside home" (p. 204). He views that to consider a weaker sex "is part of a chain of interactions that reconstitutes gender ideology" (p. 204). In this event Baburam treats Narayani as a weak person who is always in need of help. So, performing the husbandly duty, he protects her. He does not ask her whether she herself wants to deal the situation or not. He just imposes his decision on her that she accepts mutely.

Constructing the image of a subservient wife, Narayani transfers the ownership of her body from her father to her husband. This is explicitly evident in the everyday ordinariness of Narayani when she asks her husband's permission to take a job of a caretaker in a Montessori. This act of Narayani supports the belief that "Restrictions on women's demeanor outside the home are as important as the restrictions on the tasks women can do outside the home" (Derne, 1994, 205). Likewise, she confirms her subservient towards her husband. Convinced with the patriarchally injected thought that women are secure only under the arms of her husband, she appeals Baburam to not to leave her alone. She is so much dependent in him that she even does not disclose about the physical abuse done to her by Ramesh. As in the later part of the film, she reveals that since she fears that had she exposed the fact to him, he might have left him; therefore, she hid the incident (Prasad). Restricted to the role of a weakling, unassertive wife she tolerates the unbearable pain caused by the perpetrator Ramesh.

Women's role as a self-sacrificing wife is apparently evident in Narayani's act of concealing the truth about her rape to her husband. She fears that the revelation of truth may result in the end of her marriage. Since the society imposes the responsibility of saving the marriage to a wife, stifled under this responsibility, Narayani not only suppresses the truth but also mutely tolerates the pain. In Butler's (2007) perception, "gender performance is a strategy of survival within compulsory systems" (p. 178). Likewise, staple demand for woman to think about her family's honour, stops her taking action against the victimizer. Since the social mechanism compels the females to precedence the family honour, they cannot discuss about the abuse such as rape to their family members. Moreover, rape survivors are "subjected to further trauma at the hands of the very people they turn to for help. Negative reactions can thereby serve a silencing function" (Ahrens, 2006, p.264). Ahrens views that women who initially break the silence and speak out about the assault may quickly reconsider this decision and opt to stop speaking because rape and sexual abuse are viewed as a failure on the part of the woman to preserve her marital dignity. Therefore, Narayani keeps mum as she fears that 
Baburam may misunderstand her. Confirming her fear, when her pregnancy is disclosed, he defines her pregnancy as her betrayal towards him.

The sense of moral duty is ingrained not only in Narayani but also in Ramesh's wife. The self-sacrificial image of her is starkly portrayed in the film when she keeps mum even though her husband involves in offensive activities such as having extra-marital affair, expending money in night clubs, and drinking alcohol. Performing the roles of submissive wife, she does not protest against her husband's improper deeds. Furthermore, confirming to the feminine attributes such as weakness and dependency, either she sheds tears while bearing the pains of her cheater husband or she assures herself that when her father will know the truth, he will take action against her swindler husband Ramesh. Her subservience towards Ramesh gets evidently exposed when she cannot take action against her husband even after Ramesh's atrocity unfolds to her. She comes to know that Ramesh rapes Narayani, makes her pregnant, and forces her to abort. However, even in such a crucial moment, she does not deviate from the role of an unassertive, tolerant, sympathetic person. As usual, she stays mute and just sheds tears. As Butler argues that gender is "an effect of performance" (in Lloyd, 2007, 80). Later, her father asks her to take a final decision about her worthless, crook husband but again as an indecisive person she replies that "Hajura le je bhanisinchha tei [I will follow your decision]" (Prasad). Ramesh's wife repeatedly exposes the so-called feminine attributes such as indecisive, dependent, and weak in her deeds.

Throughout Prasad, Ramesh explicitly appears in the role of dominant, assertive, authoritative, and brutal person. Confirming that "masculinity actually does refer to men's engaging in toxic practices-including physical violence-that stabilize gender dominance in a particular setting" (Connell \& Messerschmidt, 2005, p. 840), he tries to keep the whole circle of friends and relatives under his control. Moreover, he behaves rudely as well as brutally to them. When he makes his first presence in the film, he seems rebuking his customers. Then, while talking to his childhood friend Baburam, he exposes his manliness through his body language. Likewise, during the conversation to Baburam, arrogance reflects in his face. Controlling Baburam's life, he takes decisions for him. He forces Baburam to increase his income and keeps his wife comfortably, he searches job for him in a nightclub, he forcefully makes him drink alcohol. Likewise, he suggests Baburam to force his wife to abort the child: "Ma bhako bhae maane thikai chha namaane ghichyaaera lagera bhae ni phaaladinthe [if I were you, I would have dragged to the hospital and abort her baby, whether she agrees or not]" (Prasad). Ramesh's expresses violence in his thoughts and ideas.

Guided by the belief that women's bodies are owned and controlled over by men, throughout the film, he tries to regulate Narayani's life. In the first meeting with Narayani in her rented room, he strongly disapproves her decision of marrying a poor, low-caste Baburam. Similarly, through his sarcastic remarks, "Yati Ramri ketilai kasari pattyais? Tero bhaagya 
raamro ho ki usko khoto ho [How did you get such a beautiful girl? Does it happen because of her bad luck or your good luck]" (Prasad), he reveals his thought that woman is an object. In his view, the more qualified object deserves to be possessed by more deserving master as he opines, "chhori maanchhe harule ali hune khaane nai keto rojnu parchaa" [girls should choose boys from a well-to-do family as their suitors] (Prasad). So, he disapproves her decision of choosing Baburam as her husband. Likewise, he tries to prove that belonging to higher class and caste than Baburam, he is more appropriate person to own her body. Therefore, he stalks her, forces her to visit the restaurant with him, flatters her beauty and even tries to convince her that she should leave her husband. When she ignores his proposal, Ramesh declares that she is a fool.

Most of the time, Ramesh affirms that a male should exhibit the superior physical power to accomplish female's body. He believes that women are made to satisfy the males' carnal desire and they should comply him, if he desires so. So, most of the time he seems in the relationship of different women because stereotype of the traditional macho man refers to be "an emotionally crippled, sex-obsessed, aggressive dominator" (Plummer, 2005, p. 182).

Similarly, he visits Narayani's room in the absence of Baburam with the intention of having sex with her but she protests his ill intention. She tells him that his presence is completely unwanted and unpleasant one for her (Prasad). Haughty Ramesh gets shock from her remarks. In fact, he feels defeated by her. Since his understanding of masculinity does not allow him to accept defeat, he rapes her.

\section{Figure 2}

Ramesh Sexually Abusing Narayani
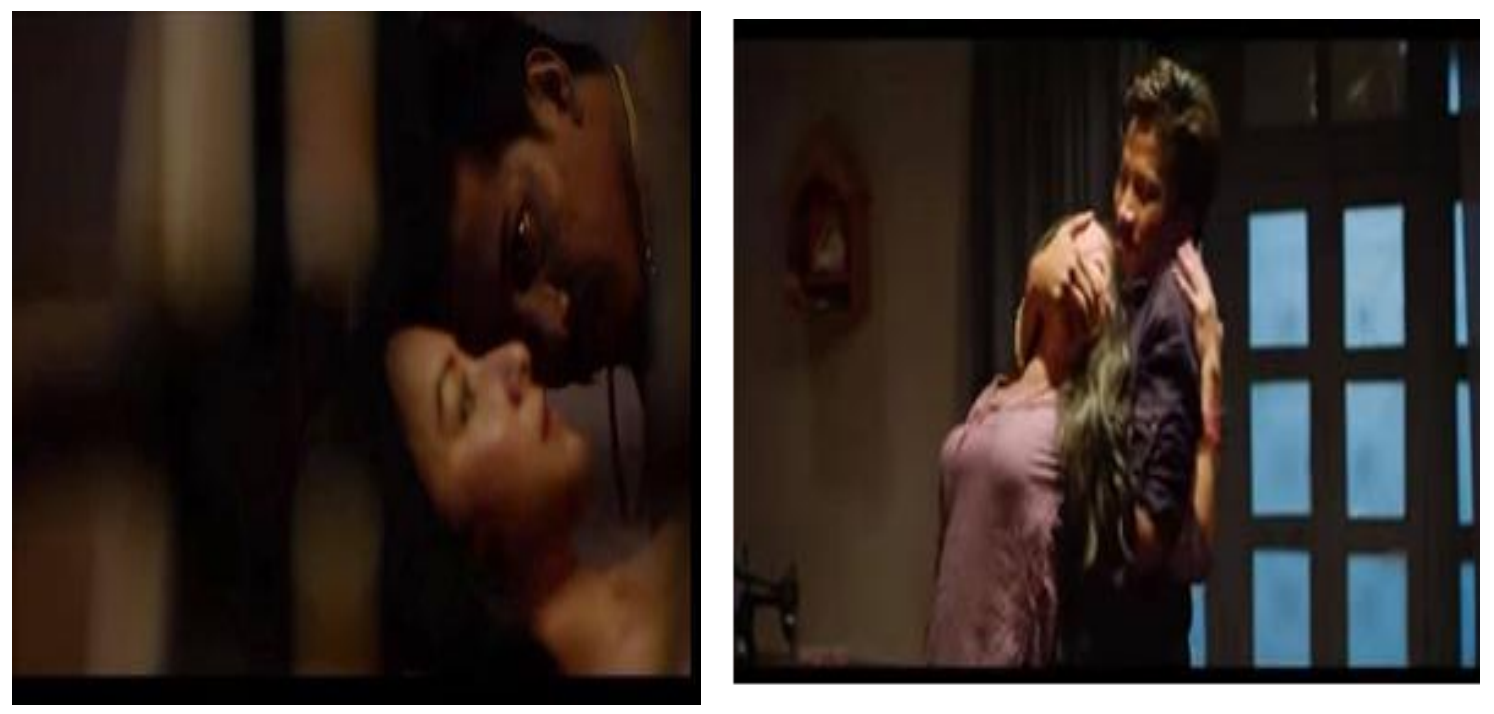


\section{Source. author's screenshot.}

In these shots Ramesh ruthlessly attacks on Narayani with the intention of satisfying his sexual thirst. In these close-up shots, the audience can clearly notice helplessness in Narayani's face and cruelty in Ramesh's countenance. Finding Narayani alone in the room he decides to acclaim masculinity that he longs to display for several days. Consequently, he possesses her body forcefully because "sexuality for men must confirm...rough and violent sex" (Plummer, 2005, p. 182). Plummer (2005) argues that for some male's masculinity means "coercive sex from rape to harassment may be felt as a central feature of a good sex" (p. 182). In thrust of exhibiting his manhood, he faultily and terribly uses these traits against Narayani. In fact, he is accustomed to use it wrongly to the females. In the conversation to Baburam he suggests Baburam to drink alcohol and grab the female's body, "Raksi chussa laaune ho ani jhamtine ho [take a sip of wine and attack]" (Prasad). Ramesh's suggestion to Baburam confirms that "gender reality is created through sustained social performances" (Butler, 2007, p.180). In the film, he seems owning the different female bodies by changing the girlfriend each day. Moreover, he continues to rule over Narayani even after doing the heinous crime against her. He pressurizes her to abort the baby. Ultimately, sensing his defeat, he tries to murder her because to get defeated by a woman, is not acceptable for him.

Prasad unravels that social norms and values ensure the maintenance, reproduction and continuation of gender image. Societal norms of that society force Narayani and Baburam to internalized values that ensure their sexuality. Since gender is maintained discursively in order to maintain for the purposes of the "regulation of sexuality within the obligatory frame of productive heterosexuality" (GT 186), the acquaintances of Narayani and Baburam reinforce the role of a parent to Baburam and Narayani. Their landlady persistently suggests them to plan for baby, the neighbor asks Narayani to learn babysitting, and her co-worker advises her for planning a baby without delay. Similarly, Baburam's friend also suggests him to think about having a child. Consequently, Narayani starts going through a guilt when she fails to conceive a baby after some months of her marriage. She thinks that failing to become a mother is to deviate from the socially prescribed role. Since "the influence of cultural stereotyping" and the "social construction of gender" influence the individual persistently (Felmlee, Sweet, \& Sinclair, 2012, p. 520), Narayani shows so much eagerness to perform the motherly role. As a result, she fails to concentrate on her works, loses appetite, and stays depressed.

Through this couple, Prasad unravels that society constrains the individual to the stereotypical gender roles through various social institutions. Connell (2009) asserts: "sex roles were acquired by socialization. Various 'agencies of socialization', notably the family, the school, the peer group and the mass media" (p.95). He views that through an immense number of small interactions, these agencies convey to the girl or the boy the social expectations for behavior. So, in the film, sensing the fact that having a power of becoming a father is related to 
the male's manhood, the gynecologist suggests Baburam not to disclose about his sterility to his wife. Consequently, Baburam goes through a great emotional pressure while maintaining the masculine image. Baburam fears that his masculine image will be shattered in case his sterility is revealed to his wife because "masculinity seems to depend chronically on the estimation of others, to be highly vulnerable to attack by ridicule, shaming, subordination, or dishonorable" (White, 1997, p.18) So, he puts his effort to hide this reality. Failure to become a father creates devastating effects in his life. Thus, he cannot concentrate in his work, he loses appetite and sleep. Then he seeks solution through alcohol confirming that drinking is "prescribed as a means of affirming masculinity" (Lemle \& Mishkind, 1989, p. 213). When Baburam fails to acclaim his masculinity, he tries to achieve it through consuming alcohol.

Baburam is guided by the belief that male should not resist or challenge the roles assigned to them. Since he believes that sterility weakens his masculinity, he puts effort on covering up the truth by secretly taking help of scientific invention such as using the doner's sperm in Narayani's womb. In order to build up a firm masculine image, Baburam converts himself to a money-making machine because he has to collect two lakhs to pay to the gynecologist. His condition confirms that "masculinity is being rather fragile, provisional, something to be won and then defended, and something under constant threat of loss" (White, 1997, p. 18). In order to protect his masculine identity, he works day and night and collects the doctor's fee. In the film, there are sequences where he works as a singer in the night club in the evening and sews customers' clothes in the day time.

Baburam is not ready to give up because he believes that males are made to win. As Gilmore (2004) points out that the males are guided by the notion that "they must pass through testing”. (p. 11). So, when Narayani's pregnancy is disclosed to him, he fears that Narayani's pregnancy threatens his masculinity. As a result, he reacts ferociously. He turns over the substances of the room, scolds and curses Narayani, spits on her, pushes her, throws a cup of tea served by her, and finally, leaves her. He takes her pregnancy as a result of unlicensed sexual relation. So, he rebukes her, "Duniyaako agaadi baau banna saktinas bhanera malaai nangyaauna khojeki [do you try to expose my sterility to the world by telling them that I cannot become a father]" (Prasad)? To accept the pregnancy of his wife is to jeopardize his masculine image, therefore, he recurrently declares, "tesalaai ra tysako naatholaai ekai thaaumaa raakhera kaatchhu" [keeping at the same place, I behead her and the adulterer] (Prasad). So, when he comes to know that Narayani's pregnancy is resulted by Ramesh's heinous crime, he moves towards Ramesh's home, carrying a stick in his hand. 
Figure 3

Baburam and Ramesh Attacking Each Other

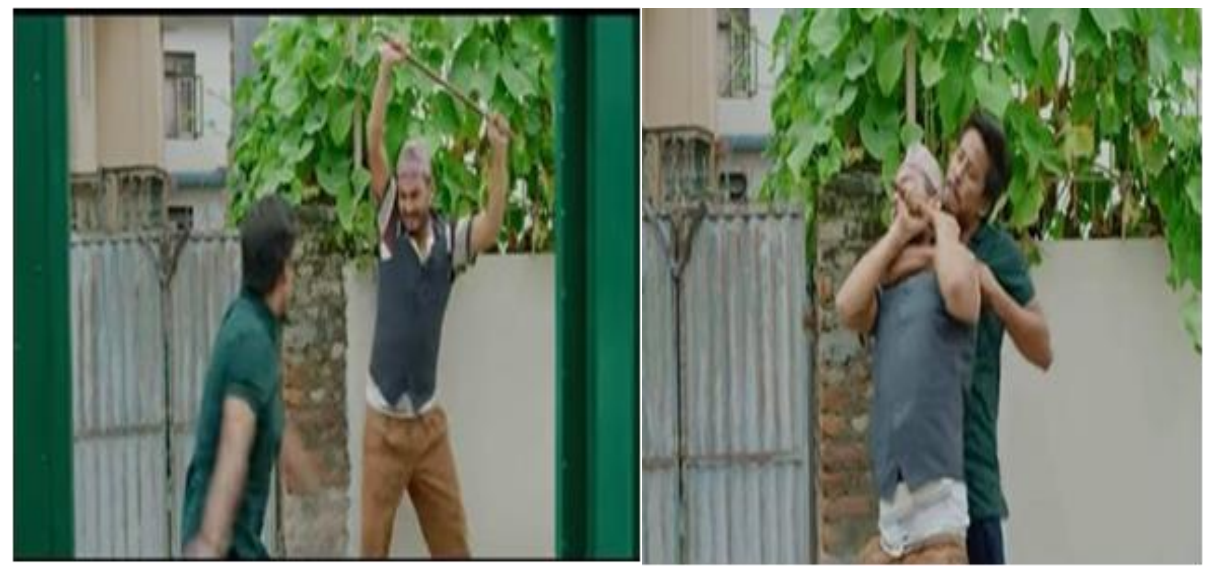

Source. Author's screenshot.

In these shots, Baburam and Ramesh seem eager to acclaim their strength over each other. These fighting sequences reveal that both of them are putting their effort to be victorious. Therefore, Baburam and Ramesh hit, push, kick, and squeeze each other.

Assigning the roles of a family-head and the protector to the males, society provides the ownership of wife to her husband. Connell (2000) claims: "Masculinity is not inherent in the male body; it is a definition given socially" (p.76). Connell, underscores that gender is socially imposed phenomena. So, when Ramesh calls him giving a threat that he is going to kill his wife, performing the role of a savior of his wife, he hurriedly reaches to the accident spot, where Ramesh plans to hit Narayani by his bike Nevertheless, in the accident, instead of Narayani, Ramesh loses his life. Due to that no one is left to take charge of pregnant Narayani as well as the baby that is growing in her belly. Therefore, though in the beginning Baburam denies to accept the baby, saying "arkaako thuk chaatne ho" [I am not the one who accepts other's leftover] (Prasad), after Ramesh's death, confirming that masculinity is "created in 
specific social circumstances and context" (Connell, 2009, p.76), Baburam perform the role of a 'protector' of Narayani and the baby. He accepts both.

\section{Conclusion}

Portraying the day-to-day activities of the major characters, who have been residing in the capital city Kathmandu for various reasons, leaving their village, Prasad unravels the gender relations among these people. Likewise, the film also highlights the triangular relationship among Narayani, Baburam, and Ramesh. These characters reinforce the concept of gender stereotyped through their thoughts and actions. After marriage, performing the role of a dutiful, dependent, and unassertive wife Narayani devotes herself in the service of her husband. Narayani gets so much engulfed in her wifely duty that she becomes depressed when she cannot conceive a baby. Similarly, after bearing the responsibility to feed Narayani as a sole bread-earner of the family, her husband Baburam behaves authoritatively to her. Throughout the film he puts his effort to stick to the image of unyielding, champion, dominator, and selfesteemed person. In the same way, exhibiting the masculine traits, Ramesh tries to control Narayani as well as Baburam's wife. He forces Baburam to raise his income and give Narayani a better life. As a dominator, he not only interferes on Narayani's life but also tries to own her body. Nevertheless, she sticking to the image of an unassertive woman, she tolerates the pain. The way these characters perform their gender emphasize the gender stereotype. This study has analyzed Prasad from the perspective of gender theory. This film can be analyzed from the perspective of cultural studies as well.

\section{References}

Adhikari, N. (2018). "Portrayal of women in Nepali movies: An analysis of three popular romantic movies." [MA Diss. Department of Media and Communication University of Oslo].

Ahrens, C. E. (2006). Being silenced: The impact of negative social reactions on the disclosure of rape. American Journal of Community Psychology, 38, 263-274.

Butler, J. (2007). Gender trouble: Feminism and the subversion of identity. Routledge.

Capraro, L. R. (2004). Men's studies. Men and masculinities: A social, cultural, and historical encyclopedia. ABC-CLIO, 1,532-535.

Chapagain, K. (2015). Rila dekhi dijitala samma [From reel to degital]. K.P. Pustak Bhandar,

Connell, R.W. (2009). Gender in world perspective. Polity Press.

---. (2000) The men and the boys. ALLEN \& UNWIN. 
Connell, R.W., \& Messersehmidt, J.W. (2005). "Hegemonic masculinity: Rethinking the concept." Gender and Society, 9(6), 829-859. http://www.jstor.org/stable/27640853

Derné, S. (1994). Hindu men talk about controlling women: Cultural ideas as a tool of the powerful. Sociological perspectives, 37(2), 203-227.

Dixit, A. (2019, December). Crime doesn't pay- Unless it's in a movie. Kathmandu Post. https://kathmandupost.com/movie-review/2019/12/14/crime-doesn-t-pay-unless-it-s-in-amovie

Felmlee, D., Elizabeth S., \& Sinclair, H. C. (2012). Gender rules: Same- and crossgender friendships norms. Sex Roles, 518-529.

Gilmore, D. D. (1990). Manhood in the making: Cultural concepts of masculinity. Yale UP.

Connell, R.W. (2004). Masculinities, relations among. In Kimmel, M. \& Aronson, A. (Eds.), Men and masculinities: A social, cultural, and historical encyclopedia. (Vol. 1, pp. 507-510), ABC-CLIO.

Haraway, J. D. (1991) Simans, cyborgs and women: The reinvention of nature. Routledge.

Kimmel, M., \& Aronson, A. (2004). Introduction. In M. Kimmel, \& A. Aronson (Eds.), Menand Masculinities: A Social, Cultural, and Historical Encyclopedia 1, xiii-xxvi. ABC-CLIO.

Lemle, R. \& Marc, E. M. (1989). Alcohol and masculinity. Journal of Substance Abuse Treatement, 6(4), 213-222.

Lloyd, M. (2007). Judith butler from norms to politics. Polity Press.

McHugh, E. (2001). Encountering the forest man: Feminine experience, imaginary others, and the disjunctions of patriarchy in Nepal. Ethos, 30(1), 77-94, University of Minnesota Press.

Newar, N. (2003). Kollywood: it's not the same old song-and-dance anymore in Nepal industry. Nepali Times, vol. 156 (8). Kathmandu. http://archive.nepalitimes.com/news.php?id=3503\#.YMHNfPkzY2w

Pilcher, J., \& Whelehan, I. (2004). 50 Key concepts in gender studies. Sage Publication.

Plummer, K. (2005). Male sexualities. In M.S. Kimmel, J. Hearn \&R.W. Connell (Eds.), Handbook of studies on men and masculinities. (pp.178-195), Sage Publication.

Pyakurel, D. (2018, December). Prasad movie review: Realistic love story blended with polished cinema art. Onlinekhabar. https://english.onlinekhabar.com/prasad-movie-review-realisticlove-story-blended-with-artistic-cinema-art.html

Subedi, R. (2012). Chalachitra sidhhaanta ra Nepali chalachitra [Film theory and Nepali film]. Pathya Saamagri Pasal.

Tamang, S. (2002, November). The sweet perfume of Numafung. Himal South Asian. https://www.himalmag.com/the-sweet-perfume-of-numafung/ 
White, S. C. (1997, June). Men masculinities and the politics of gender development. Gender and development, Vol.5, (2), 14-22. 